Volume 13 Number 1, January-March 2019: pp. 1-18. Copyright (c) 2019 FIAT JUSTISIA. Faculty of Law, Lampung University, Bandarlampung, Lampung, Indonesia. ISSN: 1978-5186 | e-ISSN: 2477-6238.

Fiat Justisia is licensed under a Creative Commons Attribution 4.0 International License, which permits unrestricted use, distribution, and reproduction in any medium, provided the original work is properly cited.

\title{
The Reconstruction of Village Governance Towards Good Governance (Study in Kalianda District, South Lampung Regency)
}

\author{
Erina Pane \\ UIN Raden Intan Lampung, Indonesia \\ erinapane@radenintan.ac.id
}

\begin{abstract}
The reconstruction of village governance begins with the promulgation of the village law to protect and empower villages to become strong, advanced, independent and democratic. This paradigmatic law to bring the changes to village governance at the regional government level. The construction of the autonomy of the village law places village arrangements as part of the concept of decentralisation and village autonomy. These changes have implications for the shift in position, extent of authority, power relations and implementation of financial policies between villages and local governments. This study used a normative-empirical approach. The results of the study showed that the implementation of the reconstruction of village governance requires a unified understanding of village government officials, village community organisations, community leaders and religious leaders regarding the principles of participation, transparency, and accountability to increase community enthusiasm, motivation and creativity in village development.
\end{abstract}

Keywords: Reconstruction, Governance, Village

How to Cite: Erina Pane, "The Reconstruction of Village Governance Towards Good Governance (Study in Kalianda District, South Lampung Regency”, Fiat Justisia, 13 (1), (2019).

DOI: https://doi.org/10.25041/fiatjustisia.v13no1.1471 


\section{A. Introduction}

Local government is an extension of the power in implementing regional autonomy to regulate and manage government affairs and the interests of local communities and as a form of recognition of the right to regulate their household affairs based on community initiatives. ${ }^{1}$ Through the principle of duties, then assignments from the national government to subnational government to carry out certain tasks accompanied by financing, facilities/infrastructure and human resources with the obligation to report on the implementation and accountable to those who assign it. ${ }^{2}$ It includes the Cities and Regency (Kabupaten), District (Kecamatan), Sub-District (Kelurahan), even Village (Desa) as the lowest tier of sub-national government in Indonesian administrative hierarchy. ${ }^{3}$

The village is the result of geographical, social, political, and cultural manifestations in an area and has a reciprocal relationship with other regions ${ }^{4}$ that have a system of self-government, ${ }^{5}$ and a legal community unit that has territorial authority to regulate and manage government affairs, the interests of the local community based on community initiatives, origins, and/or traditional rights. ${ }^{6}$

The role of the village government in implementing good governance is the implementation of the duties, functions, authorities, rights and obligations of the village government in terms of planning, implementation of development in the village, especially those related to Village Governance (tata kelola pemerintahan desa). In village governance it is necessary to pay attention to the principles of good governance including: (1) accountability which is defined as an obligation to account for its performance, (2) openness and transparency in the sense that the community cannot only access policies but also play a role in the process of formulation, (3) community participation in various general government and development activities.

Good governance as a new paradigm of administration/development management places the role of the government at the centre with the

\footnotetext{
1 Dadang Juliantara, Pembahuruan Desa, Bertumpu pada Angka Terbawah, Yogyakarta Lappera Pustaka Utama, (2003), p. 116.

${ }^{2}$ Candra Kusuma Putra, Ratih Nur Pratiwi, Suwondo, "Pengelolaan Alokasi Dana Desa dalam Pemberdayaan Masyarakat Desa dalam Pemberdayaan Masyarakat Desa", Jurnal Administrasi Publik, 1 (6), (2013), p. 2.

${ }^{3}$ Hans Antlov, Sutoro Eko, Village and Sub-District Functions in Decentralized Indonesia, Paper presented at the DSF's Closing Workshop on "Alternative Visions for Decentralization in Indonesia", Jakarta, Indonesia, March 12-13, (2012,) p. 2.

${ }^{4}$ R. Bintaro, Dalam Interaksi Desa-Kota dan Permasalahannya, Jakarta: Ghalia Indonesia, 1989, p. 19.

${ }^{5}$ Kamus Besar Bahasa Indonesia, Medan: Bitra Indonesia, (2013), p.2.

${ }^{6}$ Government Regulation Number 43 on 2014 of Implementation Regulations of Law Number 6 on 2014 Article 1.
} 
enactment of the Law No. 6 of 2014 (from now on referred to as the village law) enacted to protect and empower villages to become strong, advanced, independent and democratic. The village is a result of geographical, social, political, and cultural embodiment in an area and has reciprocal relations with other regions. $^{7}$

Changes in village governance policies with the birth of the village law paradigmatically brought changes to village governance at the regional government level. If previously the village arrangement was placed in the construction of autonomy with a focus on districts and cities, ${ }^{8}$ the village law puts village arrangements as part of the concept of decentralisation and village autonomy. These changes have implications for the shift in position, extent of authority, power relations and implementation of financial policies between villages and local governments. ${ }^{9}$

The birth of this law is expected to be able to answer the classic problems that have been related to the gap between das sollen and das sein, and misorientation between central and regional policies related to the village. However, what is the purpose of the birth of the law has still not been fulfilled, because the problems of synchronisation and misorientation between central and regional policies are still significant.

The location of this study was in Kalianda District, South Lampung Regency. South Lampung Regency has a land area of approximately 2,109.74 $\mathrm{km} 2$ which is divided into 17 districts and consists of 248 villages. ${ }^{10}$ The population of South Lampung Regency is 982,885 inhabitants. ${ }^{11}$ This study intends to examine the reality of the policy shift that occurs at the level of the regional government of South Lampung Regency, especially in the Kalianda District which consists of 25 villages and provides a complete picture related to policy shifts and its implementation for governance village in Kalianda District, South Lampung Regency.

Based on the background above, the formulation of the problem in this study is about how the reconstruction of village governance in Kalianda District is implemented and what are the inhibiting factors for the reconstruction of village governance in Kalianda District.

\footnotetext{
${ }^{7}$ Ibid.

${ }^{8}$ HAW Wijaya, Penyelenggaraan Otonomi Daerah di Indonesia, Jakarta: Raja Grafindo Persada, pp. 51 and 65.

${ }^{9}$ R. Bintaro, Loc.Cit.

${ }^{10}$ Official Portal of South Lampung Regency, District Region, https://www.lampungselatankab.go.id/sites/kabupaten, accessed on December $27^{\text {th }}, 2018$, at 9:55 PM.

${ }^{11}$ South Lampung Regency Central Bureau of Statistics, Number of Population by District and Gender in South Lampung Regency, 2016, https://lampungselatankab.bps.go.id/, accessed on December $27^{\text {th }}, 2018$, at 10:03 PM.
} 


\section{B. Research Methods}

This study used a normative-empirical approach. A normative approach is an approach through literature study by reading, quoting and analysing legal theories and legislation related to problems in research. While the empirical approach is an effort to obtain clarity and understanding of research problems based on existing realities. Data sources were obtained from literature studies, observations in villages in Kalianda District and interviews with resource persons.

\section{Discussion}

Kalianda District located at the hillside of Mount Rajabasa, along with the beach of Lampung Bay. With The population of 2,890 people, 150 of 792 families in Kalianda are poor households. While the poverty rate is $19 \%$, most of the population is a high school graduate which impact the low level of human resources in the area. This condition forced the majority of the residents to work in the agricultural and livestock sectors.

Kalianda District consists of 25 villages, namely: Agom, Babulang, Buah Barak, Bulok, Canggu, Gunung Terang, Hara Banjar Manis, Jondong, Kecapi, Kedaton, Kesugihan, Maja, Marga Catur, Merak Belantung, Munjuk Sempurna, Negeri Pandan, Palembang, Pauh Tanjung Iman, Pematang, Sukaratu, Sukatani, Sumur Kumbang, Tajimalela, Taman Agung, Tengkujuh. Furthermore, the village Governance in Kalianda will be described as follows:

\section{Village Government Apparatus Structure}

In general, the structure of village government apparatus in Kalianda District based on the authority of positions in Kalianda District includes:

\section{a. Village Head}

The village head is directly elected by the villagers, while the task of the village head is to lead the implementation of village governance based on the policy set with the Village Consultative Body (Badan Permusyawaratan Desa/Badan Hippun Pemekonan $)^{12}$ which is a policy-making body and a supervisor of village policy implementation that accommodating community aspirations. ${ }^{13}$ The village head in carrying out his duties and obligations is accountable to the village people through the Village Consultative Body and submits the report on the implementation of his duties to the regent with a copy to the Head of District (Camat).

\footnotetext{
${ }^{12}$ As stated in village law, Village Consultative Body often refer to another term. In South Lampung Regency, Village Consultative Body called as Badan Hippun Pemekonan.

${ }^{13}$ Erga Yuhandra and Gios Adhyaksa, 2018, The Effectiveness of Village Consultative Body in Kuningan District in Implementating Legislative Function, Unifikasi (Journal of Legal Studies), Kuningan, Vol. 5 No. 2, p. 108.
} 


\section{b. Village Apparatus}

\section{1) Village Secretary}

The position of the village secretary, namely as a helper of the village head, with the task, is to run the administration and development of the village community and provide administrative services.

\section{2) Head of Affairs}

The position of head of affairs is as an element of assistance to the village head in his field of work. The main task of the head of affairs is to carry out the activities of the village head in their respective fields of work. There are 5 (five) heads of village affairs, namely: head of government affairs, head of general affairs, head of financial affairs, head of development affairs, and head of public welfare affairs. The description of the main tasks and functions, according to the Minister of Home Affairs Regulation No. 84 of 2015 concerning organisational structure and work procedures of the village government.

\section{Implementation of Village Governance}

Based on the formulation of norm standards that can be used as a reference in the implementation of village governance, the implementation of governance in the Kalianda Subdistrict village, in general, it can be concluded, namely:

a. The implementation of village government, in general, is sensitive in understanding the aspirations and problems faced by the community.

b. Implementation of village governance is carried out by the village representative/consultative body the Village Consultative Body, village government and village meetings. Most of the village representative bodies have carried out the function of articulation and aggregation of the interests of the villagers, in terms of implementing budgeting functions and monitoring functions, but are still weak in the legislative function (village regulation drafting). Membership of the village representative body is chosen or based on consensus in stages by local customs and traditions. The village consultative body has reflected the representation of elements or groups within the village community but is still weak in meeting the $30 \%$ quota for women. The Village Consultative Body an institution to maintain horizontal accountability has carried out its functions. This is reflected in the village head, responsible to the people through the village consultative body, and submitting accountability information to the Bupati as material for evaluation, supervision and guidance. 
c. The village head heads the village government. Where the process of filling in the village head can be done by direct election or community meetings in stages according to local customs and traditions, the village head who is directly elected as a term of office of 6 years and can be reelected, for two terms.

d. The relationship between the village head and the village consultative body based on the principle of check balances. The village head conveyed his accountability in the form of a report on the administration of the government to the major. Information report on the administration of government at the village consultative body and residents in the village discussion forum, as well as openly informing the public.

e. Village meetings as an embodiment of consultative democracy (village consultation meeting) are the highest forum in making decisions on strategic issues in the village, for example, the establishment of village strategic plans, development planning deliberations and issues related to cooperation with third parties. Village meetings are held once a year. Village deliberations are binding to be implemented by the village government and village representative bodies. All residents can directly attend village meetings.

f. The village head is assisted by elements of the village government which includes the village secretary and village officials. The organisational structure of the village government is established through village regulations by taking into account the village model and authority. Recruitment of village secretaries and village officials is based on the principles of professionalism, transparency and accountability.

g. The organization and structure of the village's departure are based on three main village functions: (a) the function of the village government which includes carrying out public policies; hold public services; managing natural resources; and managing village finance; (b) the development function is a function of mobilizing and distributing local resources to achieve people's welfare: preparing and carrying out various sector planning; develop the local economy; development that focuses on improving basic services; manage spatial and regional arrangements; and (c) social functions are social activities based on social capital to strengthen social security.

h. The process of organising village governance opens up the space for substantive democracy, as follows:

1) Accountability refers to institutions and processes of checks and balances in the administration of village governance. Accountability means conducting a calculation of the resources or authority used. The village government is accountable for carrying out the mandate, mandate and trust given by the citizens. The village government 
carries out its duties well (for example, not committing irregularities, not committing corruption, not selling village treasury land for personal gain).

2) Transparency in policy management, finance and public services. This means that access is open to all parties interested in any information regarding policy, finance and services. Transparency is built based on the freedom to gain accessibility of adequate information flow provided to be understood and can be monitored or receive feedback from the public. Accessibility of a village especially important, determining the degree of external intervention and internal cohesiveness, the interplay of which seems to influence the ability of a community to resolve its problems. ${ }^{14}$ Transparency certainly reduces the level of uncertainty in the decision-making process and implementation of village policies, including village budget allocations.

3) Responsiveness, the village government is able and responsive to the aspirations and needs of the community, which is then used as the main preference for decision making in the village. Village officials are always ready to give a helping hand when citizens need help and service, articulate the aspirations and needs of the community, but are still weak in processing them into priority needs and formulating them into village policies.

\section{Implementation of Village Governance Reconstruction in Kalianda District}

Regional policies after the implementation of the village law have implications for changes in village governance policies in the South Lampung regency government. Changes in policy are intended to adjust to the concept of village governance that was built into the law. Over the past two years, several regional regulations have been promulgated. Regional regulations concerning appointment and dismissal of village devices; regional regulation concerning the election of village heads; and the regional regulation on village consultative bodies. Also, the South Lampung regional government also issued a recent regulation, to ensure the smooth running of village governance. From the configuration of the legal product that governs the village, it can be seen that after the enactment of this law, the South Lampung regional government did not issue too many legal products in the form of regional regulations. Regardless of the complexity of the design of village government

\footnotetext{
14 Anthony Bebbington, Leni Dharmawan, Erwin Fahmi, and Scott Guggenheim, "Local Capacity, Village Governance, and the Political Economy of Rural Development in Indonesia", World Development Journal (Elsevier), 34 (11), (2006), p. 1968.
} 
regulations at the ministerial level, these conditions can also be understood as measures of the effectiveness and efficiency of regional government work.

Based on South Lampung Regional Regulation, there are three issues which are the main focus in responding to changes in current national policies. The first, focus is related to the organisational structure and filling in positions in the village government. The South Lampung regional government is pushing for the acceleration of democratisation of village governance, through revamping the system and mechanism for the appointment and dismissal of village government officials. The issuance of the regulation is a response to the problem of accountability. However, the substance of the regional regulation did not change much from the substance of the previous regional regulation, where the process of appointing village officials did not open the space for the voting mechanism by the residents. Repairs are carried out by providing guarantees for the representation of all community members in the process of appointing village officials.

The response to changes in village government, governance-was also seen with the issuance of the regional regulation on the election of village heads. This regulation is present as part of the mandate of the minister of affair regulation no 112 of 2015 concerning the election of village heads, who want the implementation of election of village heads in each region, to be carried out simultaneously. The substance of the regulation is not only a "continuation" of the provisions above but also translates the intent of the rules above. Some of the provisions added to the regional regulation are a form of policy alignment in the minister of affair regulation with practices that have been implemented well in the village. The minister of affairs regulation also anticipates problems that often occur in the South Lampung election processes. To ensure the smooth running of the election of village heads process, the South Lampung regency government also issued two regents regulations which regulated the technical issues of the election implementation, starting from the structure and composition of the committee, election stages, candidate assessment criteria, and several other technical issues.

The restructuring of the village governance also appears from the birth of the regional regulation which regulates the structure, governance and work procedures of the village consultative body whose scope of substance has accommodated the need for the village consultative body implementation to the technical level. The existence of the regional regulation does not merely emphasise the structure of village governance, but also as part of the steps to restructure the village democracy through improving the mechanism of deliberation in the village. Through the regulation, the problems of the dishonesty of with the village consultative body village government, and 
disorientation of the village consultative body governance are expected to be resolved properly.

Bureaucratic reform at the village government level was also carried out with the issuance of the major regulation on village financial management guidelines; regent regulations concerning procedures for sharing and determining details of village funds. This regulation is a follow-up to the promulgation of the minister regulation No. 113 of 2014 concerning village financial management. Through this regulation, the local government seeks to direct village financial governance, to be more productive. These efforts are carried out by establishing clear and firm guidelines for the utilisation of village finance, both about expenditure and financing, by the village administration. An open procedural framework is carried out through the provision of space for participation by every government stakeholder and village stakeholder, starting from the planning, designing or drafting stage, to the implementation and evaluation stages.

Efforts to reform the bureaucracy through village financial structuring were also seen through the issuance of the regent's regulation on the procedure for procurement of goods/services in the village, and the regents' regulations on permanent income, allowances and other legitimate receipts for village heads and village devices. The existence of regents regulation provides clear and clear guidance on the authority and procedures for the procurement of goods and services by the village government. Whereas the regional regulation provides clarity on the financial status of the village head and all village officials, thus affecting the clarity of the allocation and transparency of public information on the utilization of the village budget. The two regents regulations have important meaning in the effort to create a clean and free government from corrupted especially to prevent abuse of power by the village apparatus.

The second, the focus of policy changes by the South Lampung regional government is related to the position of village autonomy. Since the issuance of regulation no. 6 of 2014 followed by regulation of government no. 47 of 2015 and the minister of the village no 1 of 2015, the South Lampung regional government took a responsive step by issuing a regent regulation concerning the list of Village authorities based on the origin and village-scale local authority in South Lampung regency. Through this regulation, the South Lampung regional government has established a list of village authorities, which are divided into lists of authority based on origin rights, and a list of local-scale village authorities. On the list of authorities, the village government through village consultations can choose and determine the scope of its autonomous authority. The efforts to increase community capacity and participation in government and development are reflected in the list of 
authority options for village community affairs and the field of community empowerment.

The third, the focus of policy changes by the South Lampung regional government is related to village wealth and finance. As previously explained, the South Lampung regional government has issued several policies in the form of Perbup, which provide flexibility for the village government to determine the scope of its autonomy. In addition, the South Lampung regional government also issued several regulations that synergistically provide clarity on the scope of wealth and village income sources, namely by issuing regent regulation no 15 of 2015 concerning procedures for distribution of village fund allocation, regional tax revenue sharing and regional retribution and village funds and regent regulations on the procedures for distributing and determining the amount of village funds for each village in South Lampung regency. Through this two regent regulation, the government of South Lampung provides clarity on the financial status and wealth of the village which is under the authority of the village government.

In administrative science studies, the pattern of formalistic regulation making with ansich's procedural approach as it runs in South Lampung regency contradicts the concept of good regulatory governance (GRG), which places regulation as an instrument of public service by the government, and therefore the main consideration for the government in making regulation is the aspirations of the welfare of the community. In the context of GRG, the issuance of regulation must rely on the principle of effective minimum regulation, so that the regulatory process is conscious and planned with a clear value of usefulness.

Regional regulations are a further elaboration of government policies on them. In this context, the regulations made by the regions are government instruments in achieving the targets and objectives of the mandate charged by the community, which in its preparation should open up input, suggestions and criticism from the affected community. The low quality of the legislative products of the government of South Lampung in addition to reflecting the quality of the producers also reflects the procedural quality of its manufacture. The low space for community participation and stakeholders in the regulationmaking process results in the presence of regulatory product products that are neglectful of the existence and aspirations of the village community. Based on the results of the study, it can be analysed that the reconstruction of village governance can be classified as follows:

a. Village Governance

Representative system (representation) in the form of a village consultative body with a consultative system in the form of a village consultative body (abbreviated as Bamusdes). Members of village consultative bodies are representatives of the residents of the village 
concerned determined by deliberation and consensus. In the village distortions often arise in deliberations to determine who community leaders are involved in Bamusdes. The distributor is an elitist appointment of community leaders who are considered close to the village head. The result was the lack of access of ordinary people to participate as members of Bamusdes. The Bamusdes function has not been maximised in establishing decisions with the village head, accommodating and channelling community aspirations. The control function was eliminated, thereby weakening checks and balances in the village administration. The other side is the accountability of the village head.

\section{b. Village Apparatus}

The village apparatus consists of village secretaries and other village officials. The village secretary is filled with civil servants who meet the requirements. The new provision is indeed a dilemma. The existence of a village secretary whose status is a civil servant allows service in the village office to be more secure, but this provision is a form of bureaucratisation that has a bad risk for the village administration. By the local context, village secretaries and their devices are village officials, who not only carry out administrative functions strictly but also carry out social functions that must be prepared 24 hours a day. During this time the village secretary was recruited locally and was responsible singly for the village head.

\section{c. Village Development Planning}

Villages do not have the authority to develop development plans but are given responsibilities/tasks in planning. In the framework of implementing village governance, a village development plan is prepared as a unit in the district/city regional development planning system. The position of the village is in the sub-district/city government subsystem, not stand alone as an autonomous subsystem and become part of the Indonesia Republic. Because of that condition, villages were not given the authority to develop their plans (village self-planning) or decentralised planning over villages by village authority boundaries.

The scheme did not bring significant changes, but only confirmed the bottom-up planning model starting from the Musrenbang village which had been running so far. But this Musrenbangdes scheme contains weaknesses and distortions, not only lies in the poor community participation in the village level but more importantly, that the village is powerless and does not have sufficient authority in the planning system. the village only proposes, the district determines. Participation is only a procedure. Bottom-up planning that combines sectoral approaches and spatial approaches is fatal. Regional planning output is sectoral bias, which is controlled by district technical offices, but the planning process is pursued through a spatial approach from 
the village. This process has problems at the scale level. The scale of the capacity of the village community is, of course, limited to the village jurisdiction that they see every day. The village community certainly does not have sufficient capacity to reach problems and data on larger sectoral issues outside the reach of village authority. Therefore regional planning which is sectoral bias does not depart from village community participation but is formulated technocratically by Bappeda and technical agencies. The root of the problem of all of this is the lack of clarity in the division of authority between districts and villages, and at the same time, the village has not been placed as an entity that manages development planning itself. In other words, so far it has only been familiar with regional planning but has not yet known village planning which stopped at the village level.

Aspects of community participation in localistic planning at the village level. Village development planning as referred to in paragraph (1) is prepared in a participatory manner by the village government by its authority. In preparing village development planning as referred to, it must involve village community organisations. Then the types of village planning include: (a) village medium-term development plan from now on referred for 5 (five) years; (b) the village development work plan, from now on referred for 1 (one) year.

The scheme provides the burden and responsibility to the village, not giving power and empowerment. Arranging the medium-term development plan is certainly ideal, but it also becomes a heavy burden, if the village does not obtain adequate rights and power. Village development planning is based on accurate and accountable data and information. This means that villages are forced to improve themselves in terms of data collection and village administration.

\section{d. Village Finance}

Village finance plays a very important role in the implementation of village governance, therefore in this village law plan will be clarified regarding funding authority in each activity, extracting village income sources, managing village wealth, village-supra village relations in extracting village income sources, planning and management of village revenue and expenditure budget, establishment and management of village-owned enterprises.

There are three basic principles of village finance. First, the village has the right to obtain an allocation from the government because the village carries out the functions of government, development, and society. Second, money follows function: money is used to finance functions, where this function is based on authority and village planning. Third, no mandate without funding: there is no mandate without money. This principle applies to co- 
administration tasks given to the village. The village has the right to refuse coadministration if it is not accompanied by funds, personnel, facilities and infrastructure.

In addition to village finance from local sources, it also comes from the government and third-party donations. BUMDes are alternatives that can be developed to encourage the village economy. Through this alternative business, new economic resources are expected to be created to overcome the limitations of village natural resources. Furthermore, the planning on the use of village fund allocation should be composed based on the community needs, while the community needs can be recognised through the aspirations which are implemented through the community forum. ${ }^{15}$

\section{e. Village Regulations}

As a consequence of determining the authority inherent in the village, the village has the authority (regulating, managing and being responsible) to develop village regulations. Village status in village law is even reemphasised as inseparable part from local government organisation structure, at the same time village regulation product is also emphasised as a part of regulation law which runs the government function. ${ }^{16}$ Village regulations are prepared by the village head and the village consultative body as a policy and legal framework for governance and village development. The compilation of village regulations is an elaboration of the various authorities possessed by the village, of course, based on the needs and conditions of the local village, as well as referring to higher laws and regulations. As a legal product, village regulations may not conflict with higher regulations and may not harm the public interest. As a political product, village regulations are arranged in a democratic and participatory manner. Namely the drafting process involves community participation. The community has the right to propose or provide input to the village consultative body and the village head in the process of drafting village regulations.

Facilitation of the district government towards the compilation of village regulations is very necessary to facilitate and build the capacity of the village government to develop good practices. District supervision of village regulations is very necessary so that the regulation continues to operate by legal norms, namely not deviating from the regulations above and not harming the public interest. Supervision can be in the form of preventive measures (the

\footnotetext{
15 Taufik Kurrohman, "Accountability of planning on village fund allocation in osing community in Banyuwangi", Proceedings of The International Conference on Accounting Studies (ICAS), Johor Bahru, Malaysia, 17-20 August 2015, p. 324.

${ }^{16}$ Sekar Anggun Gading Pinilih, "Model of Village Head Election Arrangement in Village Governance Law", Jurnal Dinamika Hukum, Purwokerto, 17 (2), (2017), p. 149.
} 
consultation process before draperies is ratified into a regulation) and in the form of repressive (cancelling contradictory violations).

After the village, regulation is formally established by the village head and the village consultative body next stage is the implementation of the regulation which is the responsibility of the village head. The village consultative body has the right to supervise and evaluate the implementation of village regulations. The community also has the right to conduct participatory monitoring and evaluation of the implementation of the regulation.

\section{Factors Inhibiting the Implementation of Village Governance Reconstruction in Kalianda District}

Basically, to achieve the welfare of rural communities, each of the elements of the village government and village consultative body is able to function with the support of the local community. ${ }^{17}$ Unfortunately, based on the results of the research data can be generated regarding the inhibiting factors of village governance, it turns out it does not involve much community participation. This condition has an impact on the understanding of the village administration on the conception and direction of rural policies compiled by the South Lampung regional government. The low or high level of understanding of the village government apparatus on government policies above has implications for the implementation of regional policies at the village level.

Regarding the policy of village organisation governance, most village governments cannot show the documents related to the village consultative body restructuring process. The village under study did not carry out the restructuring process as stipulated in the regional regulation. According to sources interviewed, during this time only two the village consultative body election processions have been conducted involving the community directly as existing provisions, the rest of the village consultative body elections were carried out with an acclamation appointment mechanism.

The implementation of policies at the village level can be seen from the response of the village government to regional government policies through a major regulation which outlines the obligation of the village government to issue village regulations related to the scope of village authority. Most of them were not aware of the obligation of the village government to enact village regulations. Through this research, it can be seen that the implementation of village governance in the South Lampung regional government, in general, has implemented general principles of good governance, but is still weak in

17 Ahmad Suprastiyo, "The Village Consultative Body Function in the Implementation of Village Government (A Study in Sambongwangan Village District of Randublatung Blora Regency)", Imperial Journal of Interdisciplinary Research, 2 (5), p. 201. 
several other functions, particularly related to the orderly principles of state administrators and the principle of transparency.

\section{Conclusion}

Based on the results of the research, it turns out that the village government in Kalianda District does not involve much community participation. This condition impact on the understanding of the village administration on the conception and direction of rural policies compiled by the South Lampung regional government. The low or high level of understanding of the village government apparatus in government policies above has implications for the implementation of regional policies at the village level. Regarding the policy of village organisation governance, most village governments cannot show the documents related to the village consultative body restructuring process. The village under study did not carry out the restructuring process as stipulated in the regional regulation.

In an effort to achieve maximum goals in the implementation of village governance reconstruction, improvements must be made in several respects, namely (a) the implementation of training for village officials as the village executive team on management and administration of village program management, (b) providing facilities for village officials to support the implementation of village programs. (c) understanding of the principles of participatory, transparency and accountability must be carried out as effectively as the government officials, village community organisations, community leaders and religious leaders to increase community enthusiasm, motivation and creativity in village development. 


\section{A. Book}

\section{Bibliography}

Atmosudirdjo, Prajudi. (1966). Hukum Administrasi Negara. Jakarta: Gralia Indonesia.

Fakrullah, Zudan, dkk. (2004). Kebijakan Desentralisasi di Persimpangan, Jakarta.

Juliantara, Dadang. (2003). Pembahuruan Desa, Bertumpu Pada Angka Terbawah. Yogyakarta: Lappera Pustaka Utama.

Kaho, Josep Riwu. (1996). Mekanisme Pengontrolan Dalam Hubungan Pemerintah Pusat dan Daerah. Jakarta: Bina Aksara.

Kamus Besar Bahasa Indonesia. (2013). Medan: Bitra Indonesia.

Kansil, CST. (1986). Pengantar Ilmu Hukum dan Tata Hukum Indonesia. Jakarta: Balai Pustaka.

Marbun, S.F. (2000). Pokok-pokok Hukum Administrasi Negara. Liberty. Yogyakarta.

Mardiasmo. (2004). Otonomi dan Manajemen Keuangan Daerah. Jakarta: Andi.

Ndraha, Taliziduhu. (1997). Peranan Administrasi Pemerintahan Desa Dalam Pembangunan Desa. Jakarta: Yayasan Karya Dharma IIP.

R. Bintaro. (1989). Dalam Interaksi Desa-Kota dan Permasalahannya. Jakarta: Ghalia Indonesia.

Ridwan. (2014). Diskresi \& Tanggung Jawab Pemerintah. Yogyakarta: FH UII Press.

Saputra, M. Nata. (1988). Hukum Administrasi Negara. Bandung: Alumni

Situmorang, Victor M. (1987). Pokok-Pokok Hukum Administrasi Negara. Jakarta: Bina Aksara.

Subarsono. (2010). Analisis Kebijakan Publik: Konsep, Teori dan Aplikasi. Yogyakarta: Pustaka pelajar.

Utrecht. (1960). Pengantar Hukum Administrasi Negara Indonesia. Bandung: Fakultas Hukum dan Pengetahuan Masyarakat Universitas Padjajaran.

Waldo. 1963. The Study of Public Administration. New York: Random House.

Widjaja, H.W. (2002). Otonomi Daerah dan Daerah Otonom. Jakarta: Grafindo Persada.

Widjaja, HAW. (2003). Pemerintahan Desa/Marga. Jakarta: Raja Grafindo Persada.

\section{B. Journal and Article}

Ahmad Suprastiyo, "The Village Consultative Body Function in the Implementation of Village Government (A Study in Sambongwangan Village District of Randublatung Blora Regency)", Imperial Journal of Interdisciplinary Research, 2 (5), (2016). 
Anthony Bebbington, Leni Dharmawan, Erwin Fahmi, and Scott Guggenheim, "Local Capacity, Village Governance, and the Political Economy of Rural Development in Indonesia", World Development Journal (Elsevier), $34 \quad$ (11), (2006), https://doi.org/10.1016/j.worlddev.2005.11.025.

Candra Kusuma Putra, Ratih Nur Pratiwi, Suwondo, "Pengelolaan Alokasi Dana Desa Dalam Pemberdayaan Masyarakat Desa dalam Pemberdayaan Masyarakat Desa", Jurnal Administrasi Publik, Jakarta, Vol. 1, No. 6, (2013).

Erga Yuhandra and Gios Adhyaksa, "The Effectiveness of Village Consultative Body in Kuningan District in Implementating Legislative Function", Unifikasi (Journal of Legal Studies), 5 (2), (2018), https://doi.org/10.25134/unifikasi.v5i2.922 .

Hans Antlov, Sutoro Eko, "Village and Sub-District Functions in Decentralized Indonesia", Paper presented at the DSF's Closing Workshop on "Alternative Visions for Decentralization in Indonesia”, Jakarta, Indonesia, March 12-13, (2012).

Sekar Anggun Gading Pinilih, "Model of Village Head Election Arrangement in Village Governance Law", Jurnal Dinamika Hukum, 17 (2), (2017), https://doi.org/10.20884/1.jdh.2017.17.2.789 .

Taufik Kurrohman, "Accountability of planning on village fund allocation in using community in Banyuwangi", Proceedings of The International Conference on Accounting Studies (ICAS), Johor Bahru, Malaysia, August17-20, (2015).

\section{World Wide Web}

Official Portal of South Lampung Regency, District Region, https://www.lampungselatan-kab.go.id/sites/kabupaten, accessed on December $27^{\text {th }}, 2018$, at 9:55 PM.

South Lampung Regency Central Bureau of Statistics, Number of Population by District and Gender in South Lampung Regency, 2016, https://lampungselatankab.bps.go.id/, accessed on December $27^{\text {th }}$, 2018, at 10:03 PM.

\section{Legislation}

Government Regulation Number 43 on 2014 of Implementation Regulations. Law Number 23 on 2014 of Regional Government.

Law Number 6 of 2014 of Villages.

Minister of Home Affairs Regulation Number 44 on 2016 of Village Authority. 
